\title{
Teacher Resilience and Covid-19 Seismic Disruptions: The Nigerian Experience
}

\author{
Bolaji Rachael BORODE \\ Department of Arts and Language Education, Faculty of Education, \\ Ekiti State University, Nigeria \\ E-mail: rachael.borode@eksu.edu.ng \\ Folasade Esther JIMOLA \\ Department of Arts and Language Education, Faculty of Education, \\ Ekiti State University, Nigeria \\ E-mail: folasade.jimola@eksu.edu.ng \\ Ayomiku Samuel OLANIYAN \\ Department of Arts and Language Education, Faculty of Education, \\ Ekiti State University, Nigeria \\ E-mail: ayomiku.olaniyan@eksu.edu.ng
}

Received: December 2, 2021

doi:10.5296/ire.v10i1.19542
Accepted: February 2, 2022 Published: February 11, 2022

URL: https://doi.org/10.5296/ire.v10i1.19542

\begin{abstract}
COVID-19 pandemic and its attendant problems have unleashed severe seismic disruptions on most countries of the world and have brought to the fore the fragility of most systems of the underdeveloped countries, particularly educational sector. Teachers, one of the educational stakeholders, were seemingly neglected during the COVID-19 seismic disruptions and this neglect could have far reaching impact on their cognition, psyche, self-esteem, motivation and confidence if not accorded attention against future happenings. This research therefore takes a deep dive into how COVID-19 has influenced teachers' lives, especially secondary school teachers' resilience; commitment, adaptability, confidence and the social support they received during and after the COVID-19 pandemic in both rural and
\end{abstract}


urban Nigeria. It also examines the essence of boosting resilience in teachers to promote learning, proffer and employ mitigation techniques and combat COVID -19-like situations in school environment in relation to what their cognition, skills and dispositions are with regards to novel and emergency happenings in the future. The study adopts the mixed method design using qualitative and quantitative methods of data gathering via oral interviews and questionnaires. It thereafter compares the resilience exhibited between rural based teachers and urban based teachers. The findings have implications for pre-service and in-service teacher training programmes, curriculum design, government and society engagement and teacher burn-out and attrition.

Keywords: Pandemic, Seismic, Resilience, Disruptions, Adaptability

\section{Introduction}

The teaching profession is a profession that requires total immersion of the entity of a teacher. It demands absolute, rigorous and constant use of the affective, cognitive and psychomotor aspect of whoever who would be deemed a "successful teacher", as the resultant effect of a successful teacher is quite ubiquitous; mostly seen in the outcome of learning and learners, and ironically rarely in the personal life (style) of the teacher. The teaching profession is universal and it maintains some traits, principles, ethics and norms across boundaries. According to Mogboh (2017) teachers carry out complex set of activities highly valued by the society whose reward is not dependent on economic or commensurate with remuneration especially in Nigeria. In fact, there is a saying in Nigeria that "a teacher's reward is in heaven" A teacher applies specialized knowledge, skills and attributes to provide services to meet individual and societal educational needs which in turn touch every aspect and profession in the society.

This high pressure and high expectations comes from varied sources and has a negative impact on the alarmingly high rates of teacher stress, burnout and attrition. Ferguson, Mang and Frost (2017) and Nygaard (2019) maintain that workload, student behaviour, professional relationships, societal attitudes, and employment conditions all contribute to teacher stress and burnout, which has a resultant effect on poor student outcomes (Herman, Hickmon-Rosa $\&$ Reinke, 2018). Generally in Nigeria, teacher attrition rate is suggested to be above $10 \%$ (Oke, Ajagbe, Ogbari \& Adeyeye, 2016) while particularly in the Northern part of Nigeria, teacher attrition rate increased rapidly within four years, in 2008 the rate was $13.9 \%$ but increased 20.1\% in 2012 (Garba, 2012).

\subsection{Statement of the Problem}

On 30th January 2020 the Director General of the World Health Organization (WHO) declared the outbreak of the coronavirus disease 2019 (COVID-19) a Public Health Emergency of International Concern (PHEIC). Thereafter, on 27th February 2020 the Federal Ministry of Health announced the confirmation of the first case of Corona virus disease in Nigeria, Lagos State precisely. Later, on March 19th, 2020 a circular from Federal Ministry of Education approved the closure of all schools for an initial period of one (1) month commencing from Monday 23rd March 2020 to prevent the spread of the Corona virus (COVID-19) in the country. Between February 2020 and November 30th, Nigeria had recorded 67,717 COVID-19 cases (NCDC, 2020). While on 12th of October schools were 
mandated to reopen nationwide by the Federal Ministry of Education after about seven months of sudden shut down with the believe that the worst of the pandemic was over, but as at the time of making this report another shut down was imminent due to the dreaded Second Wave of the virus across the world. The above shows the suddenness of the onslaught of the virus and its eventual disruption on educational sector in Nigeria; this is due to the fact that such disruption had never been experienced neither was it envisaged even at the beginning of the year 2020.

Apart from the disconnection that might now exist between teachers and their students, there is also the feeling of isolation from work, colleague and work environment that teachers could have. There is also the seemingly sudden thrust of teachers and students into "the new normal" as a result of the COVID-19 pandemic. New ways of teaching and learning have to be explored such as virtual learning, blended learning, and staggered school time, limited physical interaction with students and learning of new terms and concepts. The disruption and its attendant consequence coupled with the high expectations and pressure placed on teachers hitherto is the main crux of this research.

\subsection{What Is Resilience?}

Generally, resilience connotes doggedness or perseverance in the face of challenges. Over time, several disciplines have conceptualized that there are core considerations on what resilience is. Some presuppose the presence of threat to the status quo and positive reaction to instances of considerable difficulty (Luthar et al., 2000, Greenberg, 2006; Luthar \& Brown, 2007). Others argue from the perspective of nature Vs nurture. They argue that resilience is rather cultivated (nurtured) and not innate. They further emphasized that the social environment coupled with individual competences has a major role to play on resilience building (Rutter, 2006, Zucker, 2006; Gu \& Day, 2013). When thinking of teacher resilience, person-focused researchers such as Pretsch, Flunger, and Schmitt (2012) and Ghanizadeh and Royaei (2015) suggest that it is a trait that actively fosters well-being in individuals, the ability to recover strength quickly and efficiently in the face of challenges. They further explained that it is a strong sense of commitment to ones profession, self-efficacy and motivation to teach. This paper pitches its tent on teachers resilience to be ability to bounce back from setbacks and building strenght in the face of unsual stress and tough demands encounted in the teaching profession. Combining understanding of the structure of individual differences and knowledge of resilience-building process, Cooper, Flint-Taylor and Pearn (2013) grouped teachers' personal skills and attributes identified by researchers into four overlapping clusters which are adaptability, confidence, purposefulnness/commitment and social support.

\subsection{Social Support}

Constructing professional identity is a complex and nonending process, hence developing relationships with colleagues, school adminstrators, students and parents is important as forms of social support for teachers who are resilient (Le Cornu, 2013; Mansfield, Beltman \& Price 2014). Some of the indices of good social support expected during such periods i.e Covd-19 era, are good physical and online communication by observing the use of face masks, social distancing and ICT tools. Others include school managers/admisntrators having regular team meetings to assess the preparedness of both teachers and students, flexible 
working policies and practices which would cater for blended learning as a result of teachers' or students' physical absence from school, training in new skills to cope with the "new normal" and sharing of workload and expertise (Cooper, Flint-Taylor \& Pearn, 2013). Individual teachers cannot face every challenge alone, especially large, complex and novel ones such as COVID -19 and its disruptions. It is assumed that being able to approach people in the same profession during a professional crisis can help conquer such and probably even improve productivity. It is said that the degree of social cohesion and relationship with other people is one of the most powerful predictors of success during periods of challenge and stress. IQ only predicts $25 \%$ of career success while the rest is a conbination of the ability to manage social networks, stress and self-belief. Maisel and Gable (2009) expounded different kinds of networks that are made at the workplace; trust network (who can/should be confided in), information network (colleagues who get accurate and fast information to others) and advice network (colleagues who can give guidance, mentorship and advice).

However, a note of warning is sounded on the over-reliance of teachers on social support structures. Some unintended consequences could arise when support is provided, hence teachers should be on the lookout. Example of such unintended consequence is when a school administrator "encourages a supportive, consensus-driven team climate at the expense of allowing constructive challenge, and the kind of debate that fuels innovation and new achievement".

\subsection{Purposefulness}

This means having a fixed and clear goal at all times, without minding the setbacks encountered equates purposefulness. Resilient teachers according to Maddi (2013) feel in control of their lives, and tend to focus their time and energy visualizing, planning and preparing for a robust teaching experience which they can predict its outcome; this she said builds their confidence and improves their locus of control. The teaching goals which must be set in active terms should be clear, measurable, achievable, relevant and time-bound.

However, research has shown that it often takes a crisis before professionals step back and question what really matters to them. (Southwick \& Charney, 2012; Cooper, Flint-Taylor \& Pearn, 2013). Such crises are often life-changing as a result of the trauma and disruption(s) encountered, and they often lead to a realingment of goals and values to the new realities. Furthermore, Wrzesniewski, Dutton and Berg (2008) revealed that the way individuals in a profession perceive the profession affects their purposefulness and ultimately their resilience. He explained that an occupation might be seen as a job (whose main purpose is to bring food to the table or money in their pocket), a career (which provides income and affects social status) or a calling (which is loved and valued with little or no extrinsic motivation).

\subsection{Adaptability}

The main coping strategy for teachers who prefer order and structure in their classroom interaction often rely on planning and organization. As effective as this may be, it may not always work in times of unexpected rapid change or dependence on others for information, therefore flexibility must be part of the coping strategy for such teachers. Some of the ways teachers can improve their adaptability are through keeping of journal of daily events, most especially events that caused stress, how you responded and what makes you feel better. 
Other ways are learning from mistakes, taking calculated risks, devising ways of doing things in a new improved way, uncovering new problem-solving skills and looking after your physical and mental condition (Seligman, 2011; Palmer \& Cooper, 2012).

\subsection{Confidence}

Resilient people are confident in all (disruptions) they experience. The way teachers explain setbacks to themselves is important, and reframing issues more positively helps to improve confidence. Also, confidence is the willingness to take risks, admit mistakes if and when made and learning from the mistakes. Iit was further reiterated that the core techniques to building confidence are as follows: challenge all negative assumptions about your own abilities, reframe, face your fears and use reflection; identify and use natural strenghts; get in the 'flow' i.e. stretch yourself by taking on challenges.

\subsection{Research Questions}

1) What is the level of teacher resilience during COVID-19 pandemic?

2) What are the resilience skills adopted by teachers during COVID-19 disruptions?

3) Which of the resilience skills (confidence, adaptability, purposefulness/commitment and social support) do teachers mostly adopt/employ during COVID-19 disruptions?

4) What are the challenges teachers encountered during COVID-19 pandemic?

\subsection{Research Hypotheses}

1) Resilience Skills (confidence, adaptability, purposefulness/commitment and social support) have no significant relationship with teachers' resilience during COVID-19 pandemic.

2) Resilience elements (confidence, adaptability, purposefulness/commitment and social support) will not significantly contribute to teachers' resilience during COVID-19 pandemic.

3) Resilience elements have no predictive strength on teachers' resilience during COVID-19 pandemic after controlling for the effect of teachers' demographic variables (sex, age, qualification, experience, location)

\section{Methodology}

The study adopted the mixed method design using qualitative and quantitative methods of data gathering via oral interviews and questionnaire. A total of 100 teachers participated in the study. The participants were randomly drawn from public secondary schools in the 16 Local Government Areas of Ekiti State. The criterion used in selecting the participants was their willingness to participate in the study. Two instruments were used to elicit data for the study, they are; a self-constructed questionnaire on teachers due to COVID-19 and an interview guide on teacher resilience. The questionnaire consisted of 28 items which addressed the elements of resilience which are social support, adaptability, purposefulness and confidence. A four-point self-reporting scale which awarded 1,2,3,4 starting from Strongly Agree (SA), Agree (A), Disagree (D), and Strongly Disagree (SD). While the interview guide had 4 questions with which short straight to the point responses were encouraged.

The instruments were administered by the researchers with the help of 3 research assistants. The period of data collection lasted two weeks. The data collected were analysed using 
Analysis of Variance (ANOVA) while the interview guide was content analysed.

Table 1. Demographic information of Respondents

\begin{tabular}{llll}
\hline VARIABLES & GROUPING & FREQUENCY & \% \\
\hline sex & Male & 90 & 43.9 \\
Age & Female & 115 & 56.1 \\
& $20-30 \mathrm{yrs}$ & 12 & 5.9 \\
& $31-40 \mathrm{yrs}$ & 69 & 33.7 \\
& $41-50 \mathrm{yrs}$ & 74 & 36.1 \\
Qualification & N1yrs above & 50 & 24.4 \\
& NCE & 56 & 27.3 \\
& Degree & 121 & 59.0 \\
& Masters & 26 & 12.7 \\
Years & Ph.D. & 2 & 1.0 \\
Experience & 1-5yrs & 49 & 23.9 \\
& 6-10yrs & 71 & 34.6 \\
& 11-15yrs & 63 & 30.7 \\
Location & Rural & 22 & 10.7 \\
& Urban & 83 & 40.5 \\
& & 122 & 59.5 \\
\hline
\end{tabular}

From the Table 1 above, the information of the respondents under study indicated that there are 90 males (43.9\%) and 115 females (56.1\%), given a total of 205 respondents; $12(5.9 \%)$ of the respondents have lived for $20-30 \mathrm{yrs}$, 69(33.7\%) for 31-40yrs, 74(36.1\%) for 41 $-50 \mathrm{yrs}$ and $50(24.4 \%)$ for $51 \mathrm{yrs}$ and above respectively; $56(27.3 \%)$ of the respondents have bagged NCE certificate, 121(59.\%) majority have bagged first degree certificate, 26 (12.7\%) had Masters degree while only 2(1.\%) hold doctoral degree certificate. Regarding experience, $49(23.8 \%)$ had up to 5yrs teaching experience, $71(34.6 \%)$ had up to 10yrs, 63(30.7\%) had up to 15 yrs while $10.7 \%$ had more than $15 y$ rs teaching experience. Further, 83 representing 40.5 teaches in rural areas while $122(59.5)$ teaches in urban areas.

Question 1: What is the level of teacher resilience during COVID-19 pandemic? 
Table 2. Level of teacher resilience during COVID-19 pandemic

\begin{tabular}{lll}
\hline Level of Resilience & Frequency & \% \\
\hline Low $(<=26.00)$ & 75 & 36.6 \\
Moderate $(27.00-32.00)$ & 72 & 35.1 \\
High $(33.00+)$ & 58 & 28.3 \\
Total & 205 & 100.0 \\
mean & $\mathbf{2 6 . 7 9}$ & \\
S.D & $\mathbf{8 . 6 1}$ & \\
\hline
\end{tabular}

Table 2 showed that $75(36.6 \%)$ of the respondents; representing the majority had low resilience ability, $72(35.1 \%)$ had moderate resilience ability and 58 (28.3\%) had high resilience ability, given a total of 205 respondents and average resilience tendency of 26.79 . This implies that the level of teacher resilience during COVID-19 pandemic was low.

Question 2: What are the resilience skills adopted by teachers during COVID-19 disruptions?

Table 3. Mean Rating of resilience elements adopted by teachers during COVID-19 disruptions $(\mathrm{N}=205)$

\begin{tabular}{llll}
\hline Resilience Skills Adopted & Mean & Std. D & Ranking \\
\hline Confidence & 2.54 & .73 & $1^{\text {st }}$ \\
Adaptability & 2.51 & .73 & $2^{\text {nd }}$ \\
Commitment & 2.38 & .75 & $3^{\text {rd }}$ \\
Social support & 2.32 & .74 & $4^{\text {th }}$ \\
\hline
\end{tabular}

The information contained in Table 3 revealed that mean rating on resilient skills adopted by teachers during COVID-19 disruption ranges from $2.32-2.54$. However, the standard deviation which ranges from $0.73-0.75$ indicated that the respondents are very close in their ratings. This implies that resilience skills displayed by teachers during COVID-19 destruction are confidence, adaptability, commitment and social support.

Question 3: Which of the resilience skills (confidence, adaptability, purposefulness/commitment and social support) do teachers mostly adopt/employ during COVID-19 disruptions?

From Table 3 above, the most resilience skills adopted was confidence skill (mean=2.54). This is closely followed by adaptability (mean=2.51) and commitment (mean=2.38) while social support (mean=2.32) is the least in the ranking order.

Question 4: What are the challenges teachers encountered during COVID-19 pandemic?

The interview guide was used to gain information on the challenges faced during the 
COVID-19 pandemic by teachers. 40 of the total sample of teachers responded to the interview guide, 18 being from rural areas of the state while 22 were from the urban centers. Of the two groups it was discovered that $77.5 \%$ indicated that the major challenge they faced was lack of social support. Some of the words used to describe their lack of social support include loneliness, lack of connection to the real world, being out of the loop. While the next ranking challenge inferred from the respondents was fear of adapting, both by themselves, their colleagues and their students. $67.5 \%$ of the interviewees did not know how to adapt smoothly to the "new normal" of wearing of face masks while in public and washing of hands at regular intervals and social distancing from colleagues and students.

Hypothesis 1: Resilience skills (confidence, adaptability, purposefulness/commitment and social support) have no significant relationship with teachers' resilience during COVID-19 pandemic.

Table 4. Pearson Product Movement Correlation of relationship between resilience skills adopted by teachers and their resilience ability during COVID-19 disruption

\begin{tabular}{llllll}
\hline & Resilience & Confidence & Adaptability & Commitment & $\begin{array}{l}\text { Social } \\
\text { Support }\end{array}$ \\
\hline Resilience & 1 & & & & \\
Confidence & $.462^{*}$ & 1 & & & \\
Adaptability & $.442^{*}$ & $.764^{*}$ & 1 & & \\
Commitment & $.346^{*}$ & $.616^{*}$ & $.785^{*}$ & 1 & 1 \\
Social Support & $.487^{*}$ & $.627^{*}$ & $.742^{*}$ & $.757^{*}$ & 1 \\
\hline
\end{tabular}
${ }^{*} \mathbf{p}<\mathbf{0 . 0 5}$.

Table 4 shows that there exist positive and significant relationship between each of the resilience skill elements [confidents skill $(r=.462, p<0.05)$, adaptability skill $(r=.442, p<0.05)$, commitment skill $(\mathrm{r}=.346, \mathrm{p}<0.05)$ and social support skill $(\mathrm{r}=.487, \mathrm{p}<0.05)]$ and teachers' resilience ability during COVID-19 disruption. Thus, the null hypothesis was rejected. This implies that increase in teachers' confidence, adaptability, commitment and social support skills will yield more resilience ability on the part of teachers. Therefore, there is significant relationship between resilience skills adopted by teachers and their resilience ability during COVID-19 disruption.

Hypothesis 2: Resilience elements (confidence, adaptability, purposefulness/commitment and social support) will not significantly contribute to teachers' resilience during COVID-19 pandemic. 
Table 5. Multiple Regression Analysis of Contribution of resilience elements to teachers' resilience during COVID-19 disruption

\section{Model Summary}

\begin{tabular}{|c|c|c|c|c|c|c|}
\hline Model & $\mathbf{R}$ & R Square & & Adjusted R Square & Std. Eı & \\
\hline 1 & .538 & .290 & & .275 & 7.335 & \\
\hline ANOV & & & & & & \\
\hline Model & & $\begin{array}{l}\text { Sum } \\
\text { Squares }\end{array}$ & Df & Mean Square & $\mathbf{F}$ & P-value \\
\hline 1 & Regression & 4385.784 & 4 & 1096.446 & 20.377 & .000 \\
\hline & Residual & 10761.611 & 200 & 53.808 & & \\
\hline & Total & 15147.395 & 204 & & & \\
\hline
\end{tabular}

\section{COEFFICIENTS}

\begin{tabular}{llllll} 
Model & \multicolumn{2}{l}{ Unstandardized Coefficients } & $\begin{array}{l}\text { Standardized } \\
\text { Coefficients }\end{array}$ & T & P-value \\
& B & Std. Error & Beta & & \\
$($ Constant) & 10.762 & 1.997 & & 5.390 & .000 \\
Confidence & .729 & .274 & .248 & 2.658 & .008 \\
Adaptability & .325 & .353 & .111 & .919 & .359 \\
Commitment & -.556 & .302 & -.195 & -1.838 & .068 \\
Social support & 1.144 & .285 & .397 & 4.014 & .000 \\
\hline
\end{tabular}

Table 5 shows that $F=20.377 \mathrm{p}<0.05$ ) at 0.05 level of significance. Since P-value of 0.000 is less than 0.05 level of significance, the null hypothesis is rejected. Therefore, resilience elements (confidence, adaptability, purposefulness/commitment and social support) significantly contributed to teachers' resilience during COVID-19 pandemic. The result further showed positive correlations between the resilience skills adopted by the teachers and resilience ability during COVID-19 disruption at 0.05 level of significance $(\mathrm{R}=0.538$; $\mathrm{p}<0.05)$. Also, all the resilience skills adopted by teachers during COVID-19 disruption jointly account for about $29.0 \%\left(\mathrm{R}^{2}=0.290 \times 100\right)$ of the observed variance in teachers' resilience ability while the variables not cover in this study assumed to be responsible for the remaining $71.0 \%$. Individually, social support skill was the only single best predictor of teachers' resilience ability during COVID-19 disruption with 0.397 beta weight. This closely followed by coordinating confidence skill with 0.248 beta weight.

Hypothesis 3: Resilience elements have no predictive strength on teachers' resilience during COVID-19 pandemic after controlling for the effect of teachers' demographic variables (sex, age, qualification, experience, location) 
Table 6. Hierarchical Multiple Regression Analysis of Contribution of resilience skills to teacher resilience during COVID-19 disruption after controlling for demographic variables

\section{Model Summary}

$\begin{array}{llllll}\text { Model } & \mathrm{R} & \mathrm{R}^{2} & \text { Adjusted } \mathrm{R}^{2} & \text { Std. } & \text { Error } \\ \text { Change Statistics }\end{array}$

\begin{tabular}{|c|c|c|c|c|c|c|c|c|}
\hline & & & $\begin{array}{l}\text { of the } \\
\text { estimate }\end{array}$ & $\mathrm{R}^{2} \Delta$ & $\mathrm{F} \Delta$ & df1 & df 2 & Sig. F $\Delta$ \\
\hline $.083^{\mathrm{a}}$ & .007 & -.018 & 8.694 & .007 & .276 & 5 & 199 & .926 \\
\hline $.541^{\mathrm{b}}$ & .293 & .260 & 7.410 & .286 & 19.72 & 4 & 195 & .000 \\
\hline
\end{tabular}

\section{ANOVA}

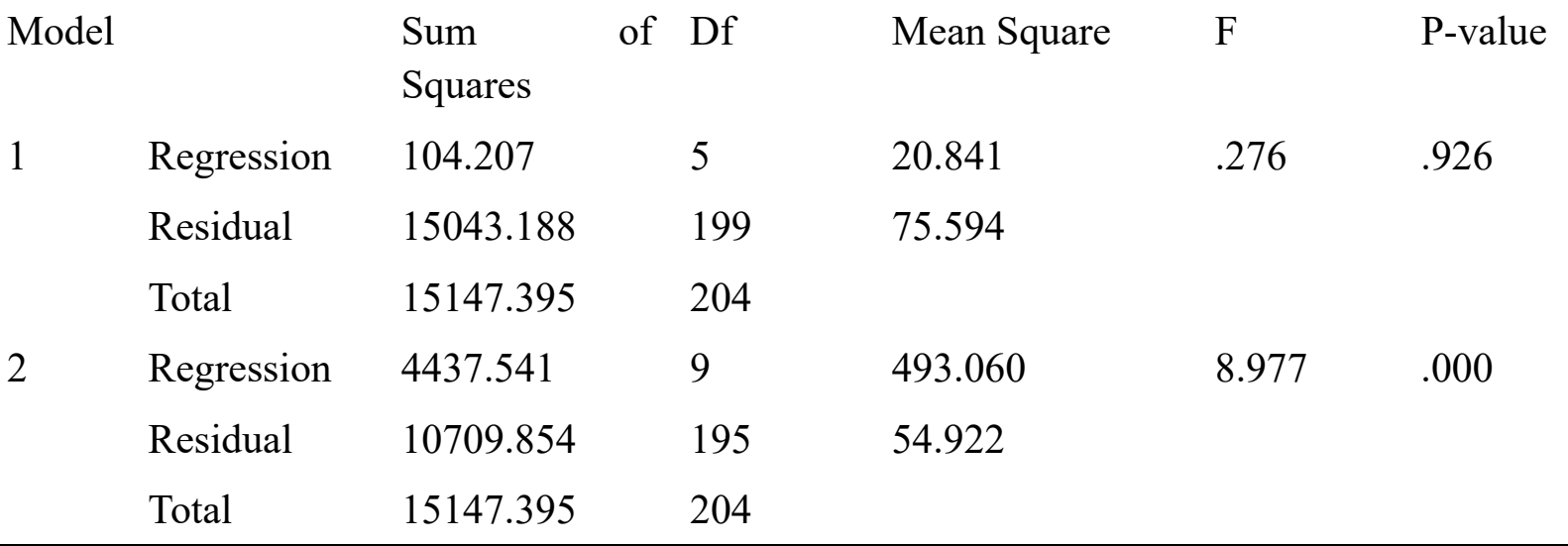

\section{Coefficients}

\begin{tabular}{|c|c|c|c|c|c|c|}
\hline \multicolumn{2}{|c|}{ Model } & \multicolumn{2}{|c|}{ Unstandardized Coefficients } & \multirow{2}{*}{$\begin{array}{l}\text { Standardized } \\
\text { Coefficients } \\
\text { Beta }\end{array}$} & \multirow[t]{2}{*}{$\mathbf{t}$} & \multirow[t]{2}{*}{ P-value } \\
\hline & & $\mathbf{B}$ & Std. Error & & & \\
\hline \multirow[t]{6}{*}{1} & (Constant) & 26.348 & 4.222 & & 6.240 & .000 \\
\hline & Sex & -.515 & 1.248 & -.030 & -.413 & .680 \\
\hline & Age & -.473 & .760 & -.048 & -.622 & .535 \\
\hline & Qualification & .449 & .956 & .034 & .470 & .639 \\
\hline & Experience & .303 & .712 & .033 & .426 & .671 \\
\hline & Location & .650 & 1.252 & .037 & .519 & .604 \\
\hline \multirow[t]{7}{*}{2} & (Constant) & 9.527 & 4.153 & & 2.294 & .023 \\
\hline & Sex & .319 & 1.071 & .018 & .298 & .766 \\
\hline & Age & -.226 & .651 & -.023 & -.348 & .728 \\
\hline & Qualification & .325 & .817 & .025 & .397 & .692 \\
\hline & Experience & .462 & .609 & .051 & .759 & .449 \\
\hline & Location & -.268 & 1.082 & -.015 & -.248 & .805 \\
\hline & Confidence & .732 & .279 & .249 & 2.623 & .009 \\
\hline
\end{tabular}


Adaptability $\quad .310$

.358

.106

.865

.388

Commitment $\quad-.528$

.309

$-.185$

$-1.708$

.089

Social

1.142

.288

.396

3.957

.000

Support

Table 6, Hierarchical multiple regression was used to assess the ability of four resilience skills (confidence, adaptability, commitment and social support) to predict levels of teachers' resilience ability after controlling for the influence of their demographic variables. Demographic variables were entered at Step 1, explaining $0.7 \%$ of the variance in teachers' resilience ability. After entry of the resilience skills at Step 2 the total variance explained by the model as a whole was $29.3 \%, F(9,195)=8.977, p<.05$. This implies that the two resilience skills explained an additional $28.6 \%$ of the variance in teachers resilience ability, after controlling for demographic variables, $R$ squared change $=.286, F$ change $(4,195)=$ $19.72, p<.001$. In the final model, only confidence and social support skill were statistically significant, with the social support skill recording a higher beta value (beta $=396, p<.05$ ) than the confidence skill $($ beta $=.249, p<.05)$.

\section{Findings from the Research Hypotheses}

1) Resilience skills displayed by teachers during COVID-19 destruction are confidence, adaptability, purposefulness/commitment and social support.

2) The skills have significant relationship with teachers' resilience during COVID-19 pandemic.

3) The skills significantly contributed to teachers' resilience during COVID-19 pandemic.

4) Teachers' qualification had no significant influence on teachers' resilience during COVID-19 pandemic.

5) Location had no significant influence on teachers' resilience during COVID-19 pandemic.

6) Year of service had no significant influence on teachers' resilience during COVID-19 pandemic.

\section{Discussion}

The study revealed that the level of teacher resilience during COVID-19 pandemic was low. It was discovered from the study that resilience skills adopted were confidence skill, closely followed by adaptability, commitment while social support was the least in the ranking order. This finding countered the study of Mwivanda and Kingi (2018) who examined teachers' resilience on students' academic performance. The results revealed high moderate level of teachers' resilience. The findings of the present study indicated that the major challenge was lack of social support which included loneliness and lack of connection to the real world while the fear of adapting by themselves, their colleagues and their students to the "new normal" posed threat. This study also examined the effects of teachers' resilience elements on teachers' demographic variables (sex, age, qualification, experience, location). The study showed that teachers' demographic variables had no significant influence on teacher resilience during COVID-19 pandemic. This finding is supported by Brouskeli, Kaltsi and 
Loumakou (2018) who investigated resilience and teachers' demographic variables (sex, age, qualification, experience and location). They found out that there was no significant differences in resilience levels according to the participants' gender, although the average rank of women was slightly higher than that of men. Also, teacher resilience levels were not significantly differentiated according to the age group and years of teaching experience of the participants. However, there were significant differences in the resilience scale scores among those teachers who had received a second undergraduate qualification, those who had a postgraduate qualification, and those who had only concluded their first undergraduate degree. Also, the study's results also revealed that teachers in big cities showed lower levels of resilience compared to teachers in semi-urban and residential zones. Also in a study of Mwivanda and Kingi (2018), they discovered that gender, length of service and education qualification did not make any difference in relation to teachers' resilience.

\section{Recommendations}

Teachers should be motivated and encouraged to boost their resilience should there be any emergence of COVID-19-like pandemic in the future since such will increase their resilience, most importantly in the area of social support given to them. According to Luthar and Brown (2007) "Relationships lie at the 'roots' of resilience... the presence of support, love, and security fosters resilience in part, by reinforcing people's innate strengths". Social contact and support according to Hauken (2020) may help to reduce stress, anxiety and fear of isolation, and improve self-esteem during unprecedented situations.

School administrators and educational policy makers should encourage and provide an unofficial and informal platform whether virtual or physical where teachers and educators alike can relate with one another on issues affecting them which could further help educators deal with the uncertainties of their changing world. Furthermore, it should be noted that virtual/ online education has come to stay, therefore teachers should be equipped with gadgets and resources, online applications and knowledge on how to stay connected with their students during COVID-19-like situations, as no one can say for certainty if the end has be seen of lockdowns and restrictions caused by the COVID-19.

\section{References}

A. O. Oke, M. A. Ajagbe, M. E. Ogbari \& J. O. Adeyeye. (2016). Teacher retention and attrition: A review of the literature. Mediterranean Journal of Social Sciences, 7(2), 371-378. https://doi.org/10.5901/mjss.2016.v7n2s1p371

Brouskeli, V., Kaltsi, V., \& Loumakou, M. (2018). Resilience and occupational well-being of secondary education teachers in Greece. Issues in Educational Research, 28(1), 43-60.

Cooper, C. L., Flint-Taylor, J., \& Pearn, M. (2013). Building Resilience for Success. A Resource for Managers and Organisations. New York: Palgrave Macmillan. https:/doi.org/ $10.1057 / 9781137367839$

Garba, N. A. (2012). An outlook on Educational system in Northern Nigeria. Journal of Teacher Education, 3(2), 5-11.

Ghanizadeh, A., \& Royaei, N. (2015). Emotional facet of language teaching: Emotion regulation and emotional labor strategies as predictors of teacher burnout. International Journal of Pedagogies, 10(2), 139-150. https://doi.org/10.1080/22040552.2015.1113847 
Greenberg, M. (2006). Promoting resilience in children and youth: Preventive interventions and their interface with neuroscience. Annals of the New York Academy of Sciences, 1094, 139-150. https://doi.org/10.1196/annals.1376.013

$\mathrm{Gu}$, Q. \& Day, C. (2013). Challenges to teacher resilience; conditions count. British Educational Research Journal, 39, 22-44.

Gu, Q., \& Day, C. (2007). Teachers' resilience: A necessary condition for effectiveness, Teaching and Teacher Education, 23, 1302-1316. https://doi.org/10.1016/j.tate.2006.06.006

Hauken, M. A. (2020) Importance of social support during the coronavirus outbreak. https://www.uib.no/en/ccp/134845/importance-social-support-during-coronavirus-outbreak

Herman, K. C., Hickmon-Rosa J. \& Reinke, W. M. (2018). Empirically Derived Profiles of Teacher Stress, Burnout, Self-Efficacy, and Coping and Associated Student Outcomes. Journal of Positive Behavior Interventions, 20(2), 90-100. https://doi.org/10.1177/1098300 717732066

Kristen, F., Colin, M., \& Lorraine, F. (2017). Teacher stress and social support usage. Brock Education Journal, 26(2), 62-86. https://doi.org/10.26522/brocked.v26i2.606

Le Cornu, R. (2013). Building early career teacher resilience: The role of relationships. Australian Journal of Teacher Education, 38(4), 1-16. https://doi.org/10.14221/ajte.2013 v38n 4.4

Luthar, S., \& Brown, P. (2007). Maximizing resilience through diverse levels of inquiry: Prevailing paradigms, possibilities, and priorities for the future. Development and Psychopathology, 19, 931-955. https://doi.org/10.1017/S0954579407000454

Luthar, S. S., Cicchetti, D., \& Becker, B. (2000). The construct of resilience. A critical evaluation and guidelines for future work. Child Development, 71, 543-562. https://doi.org/10.1111/1467-8624.00164

Maddi, S. R. (2013). Personal hardiness as the basis for resilience. In Hardiness. Dordrecht: Springer. https://doi.org/10.1007/978-94-007-5222-1

Maisel, N., \& Gable, S. L. (2009). The Paradox of Received Social Support: the Importance of Responsiveness. Psychological Science, 20, 928-932. https://doi.org/10.1111/j.14679280.2009.02388.x

Mansfield, C., Beltman, S., \& Price, A. (2014). I'm coming back again! The resilience process of early career teachers. Teachers and Teaching: Theory and Practice, 20(5), 547-567. https://doi.org/10.1080/13540602.2014.937958

Mogboh, V. (2017). The teaching profession: an interesting journey. Enugu, Nigeria: Ezu Books Limited.

Mwivanda, M., \& Kingi, P. (2018). Teachers' resilience on students academic performance in public secondary schools in selected counties Kenya, Zambia. Journal of Popular Education in Africa, 3(2), 18-30.

Nygaard, K. (2019). The Causes of Teacher Burnout and Attrition. https://digitalcommons. csp.edu: (December 28, 2020)

Palmer, S. \& Cooper, C. (2012). How to Deal with Stress. London: How to Deal with Stress. Pretsch, J., Flunger, B., \& Schmitt, M. (2012 ). Resilience predicts well-being in teachers, but 


\section{Macrothink}

International Research in Education

ISSN 2327-5499 2022, Vol. 10, No. 1

not in non-teaching employees. Social Psychology of Education, 15, 321-336. https://doi.org/10.1007/s11218-012-9180-8

Progression of COVID-19 cases in Nigeria. (2020). https://covid19.ncdc.gov.ng/: https://covid19.ncdc.gov.ng/progression/

Rutter, M. (2006). Genes and behavior: Nature-nurture interplay explained. New, Jersey: Blackwell Publishing. https://doi.org/10.1101/gad.1363606

Seligman, M. (2011). Flourish. New York: Free Press.

Southwick, S. M. \& Charney, D. S. (2012). Resilience: The Science of Mastering Life's Greatest Challenges. Cambridge: Cambridge University Press. https://doi.org/10.1017/ CBO9781139013857

Wrzesniewski, A, Dutton J. E., \& Berg J. M. (2008). What-is-Job-Crafting-and-Why-Does-itMatter1.pdf.https://positiveorgs.bus.umich.edu/wp-content/uploads/What-is-Job-Crafting-and -Why-Does-it-Matter1.pdf (December 15, 2020)

Zucker, R. (2006). Alcohol use and the alcohol use disorders: A developmental-biopsychosocial systems formulation covering the life course. In D. C. Cohen, Developmental psychopathology: Vol. 3. Risk, disorder, and adaptation (pp. 620-656). New York: Wiley. https://doi.org/10.1002/9780470939406.ch17

\section{Copyright Disclaimer}

Copyright for this article is retained by the author(s), with first publication rights granted to the journal.

This is an open-access article distributed under the terms and conditions of the Creative Commons Attribution license (http://creativecommons.org/licenses/by/4.0/). 